Y. et al.: J. Thorac. Cradiovasc. Surg. 82: 629, 1981. 5) Castaneda, A. R. et al.: Ann. Thorac. Surg. 38 : 439, 1984. 6) Idriss, F.S. et al.: J. Thorac. Cardiovasc. Surg. 95 :
255, 1988. 7) Duster, M.C. et al.: Am. Heart J. 109 : 1323, 1985. 8) Wernovsky, G. et al.: Circulation 77 : 1333，1988.9）安井久喬ほ加: 手術 $42: 85,1988$.

\title{
S-II-7 完全大血管転位症の外科治療
}

一Mustard procedure から新生览期動脈側スイッチ手術まで一

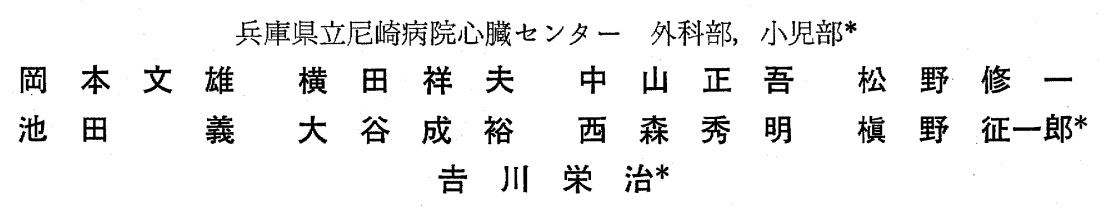

1988 年 12 月までに TGA I 群， II群，Taussig-Bing 奇形 97 例に根治手術を行った. 1969〜 75 年の期間は 39 例全例 Mustard 手術であった. 1976 年当施設であ Jatene 手術を開始したが，当初成績はきわめて不良で あった. その後 Damus ${ }^{1)}-$ Kaye $^{2)}$-Stansel ${ }^{3)} ら の$ proposal による冠動脈移植を必要としない解剖学的修復術の成功 例を得て以来, 1976〜82 年の間に 7 例に本術を行った. 1982 年 Lecompte ${ }^{4)}$ らの French maneuver の報告以 降 Jatene 手術成績は安定し, 1983 88 年の期間は 23 例中 22 例に Jatene 手術を含む動脈側スイッチ手術を 行った（表 1 ).

さらに動脈側スイッチ手術の対象が新生児まで拡大さ れた現在, 手術成績向上のためには術式, 補助手段など にいっそうの工夫が要求されてくる. 一方また Jatene 手術後最む多くみられる合併症である肺動脈狭窄（以下 PS) あ今後の課題である.

\section{対象}

1983 年から 1988 年までに根治手術を行った TGA I 群 10 例, 術式別に Senning 手術 1 例, Damus-KayeStansel 手術 1 例, Jatene 手術 8 例 (Lecompte 法 8 例), TGA II群执よび Taussig-Bing 奇形 13 例, 術式 別化 Jatene 手術 12 例 (Lecompte 法 10 例), 川島手 術 1 例, 計 23 例である.

\section{成 績}

TGA I 群一期的 Jatene 手術 4 例 (死亡 1 ), 手術時 月踰は 12 日〜 6 か月, 平均 2 か月である. I群に対す る Senning 手術症例は, Jatene 手術待期中に急速な多 血症の進行に伴い血小板数が 1 万以下まで減少したため ヘパリン療法, 瀉血など行ったが改善がえられず術中, 術後の出血を㲘念して Senning 手術を施行した. I 群 に対する二期的手術は 5 例 $(0)$, うち 1 例は Jatene 手

表 1 術式の変遷 (TGA I, II, Taussig-Bing 奇形)

\begin{tabular}{|c|c|c|c|c|c|c|c|c|c|}
\hline & \multicolumn{4}{|c|}{ 心房内血流転換術 } & \multicolumn{4}{|c|}{ 動脈側スイッチ手術 } & \multirow[b]{2}{*}{ 川 島 } \\
\hline & \multicolumn{2}{|c|}{ Mustard } & \multicolumn{2}{|c|}{ Senning } & \multicolumn{2}{|c|}{ D-K-S* } & \multicolumn{2}{|c|}{ Jatene } & \\
\hline & $\mathrm{I}$ & II \& T-B** & $I$ & II \& T-B & I & II \& T-B & $I$ & II \& T-B & T-B \\
\hline $1969 \sim 1975$ & 13 & 26 & 0 & 0 & - & - & - & - & 0 \\
\hline $1976 \sim 1982$ & 17 & 7 & 0 & 0 & 1 & 6 & 1 & 3 & 0 \\
\hline \multirow[t]{2}{*}{$1983 \sim 1988$} & 0 & 0 & 1 & 0 & 1 & 0 & 8 & 12 & 1 \\
\hline & \multicolumn{2}{|c|}{63} & \multicolumn{2}{|c|}{1.} & \multicolumn{2}{|c|}{8} & \multicolumn{2}{|c|}{24} & 1 \\
\hline
\end{tabular}

* D-K-S: Damus-Kaye-Stansel op.

** T-B: Taussig-Bing 奇形 
表 2 成 績

\begin{tabular}{|c|c|c|c|c|c|}
\hline 病 型 & 術 & 式 & 症例 (死亡) [遠隔死] & 手術時月齢 (平均) & 考 \\
\hline \multirow{4}{*}{ TGA (I) } & \multirow{2}{*}{ 一期的 } & Jatene & $4(1)$ & $12 \mathrm{~d} \sim 6 \mathrm{~m}(2 \mathrm{~m})$ & 新生児 2 例 \\
\hline & & Senning & $1(0)$ & $7 \mathrm{~m}$ & 多血症による PH 血小板減少著明 \\
\hline & \multirow{2}{*}{ 二期的 } & Jatene & $4(0)$ & $12 \mathrm{~m} \sim 22 \mathrm{~m}(18 \mathrm{~m})$ & \multirow[b]{2}{*}{ intramural coronary artery } \\
\hline & & D-K-S & $1(0)$ & $9 \mathrm{~m}$ & \\
\hline \multirow{3}{*}{ TGA (II) \& T-B } & \multirow{2}{*}{ 一期的 } & Jatene & $8(1)[1]$ & $1 \mathrm{~m} \sim 12 \mathrm{~m}(6 \mathrm{~m})$ & \\
\hline & & 川 島 & $1(1)$ & $33 \mathrm{~d}$ & \\
\hline & 二期的 & Jatene & $4(1)[1]$ & $11 \mathrm{~m} \sim 30 \mathrm{~m}(23 \mathrm{~m})$ & $\begin{array}{l}\text { 手術死症例は，右銷骨下動脈右肺 } \\
\text { 動脈起始 }\end{array}$ \\
\hline
\end{tabular}

$23(4)[2]$

(KAH, June '89)

術の予定でのぞんだが，術中 intramural coronary artery の存在が確認されたため Damus-Kaye-Stantel 手 術を施行した. TGA II 群および Taussig-Bing 奇形に 対する一期的手術は 9 例. Jatene 8 例(1)〔遠隔死 1]，川島手術の1例は，大血管が side by side の Taussig-Bing 型であったため本術式を行った. 二期的 Jatene 手術 4 例 (1)〔1〕である（表2）。開心補助手 段は，低体温体外循環法 19 例 (死亡 3 ) である. うちわ けは TGA I 群一期的手術 (Jatene) 3 例 (1), 手術時 月齢 $2.7 \pm 2.9$ 加月, 手術時体重 $4.4 \pm 1.4 \mathrm{~kg}$, 総体外 循環時間 $282 \pm 64$ 分, 大動脈遮断時間 $117 \pm 10$ 分. 同 (Senning) 1 例(0) 7 加, $6.3 \mathrm{~kg}, 190$ 分, 102 分. I 群二期的手術 (Jatene, Damus-Kaye-Stansel) 5 例 (0), $16.6 \pm 5.9$ 加月, $9.2 \pm 1.5 \mathrm{~kg}, 364 \pm 84$ 分, 179 土35 分. TGA II 群および Taussig-Bing 奇形に対す る一期的手術 (Jatene) 6 例 (1)，5.5土3.1 加月，5.3 $\pm 1.0 \mathrm{~kg}, 378 \pm 111$ 分, $163 \pm 30$ 分. II 群および TaussigBing 奇形二期的手術 (Jatene) 4 例 (1) 23.3土9 加月, $8.7 \pm 1.7 \mathrm{~kg}, 437 \pm 133$ 分, $208 \pm 39$ 分. また体外循環 併用超低体温循環遮断法（以下循環遮断法）は 4 例 (1) である.うちわけは TGA I 群一期的手術 (Jatene) 1 例 $(0) ， 14$ 日， $3.0 \mathrm{~kg} ， 172$ 分，119 分（循環遮断時間 104 分). TGA II 群および Taussig-Bing 奇形一期的手

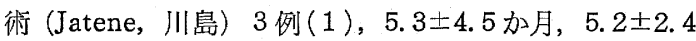

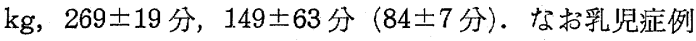
では体外循環回路に除水回路を併設し，また大動脈遮断 中の心筋保護は全例 cold blood cardioplegia を順行性 に行った.

動脈側スイッチ手術を行った 22 例を対象に，総体外 循環時間, 大動脈遮断時間と手術成績との関係を検討し た（図 1)。乙れによって新生児症例では総体外循環時 が 250 分を越えると全身浮腫が著しく，手術予後が悪く
〈䌊体外偱㜊時間〉

〈大動脈遮断時間〉
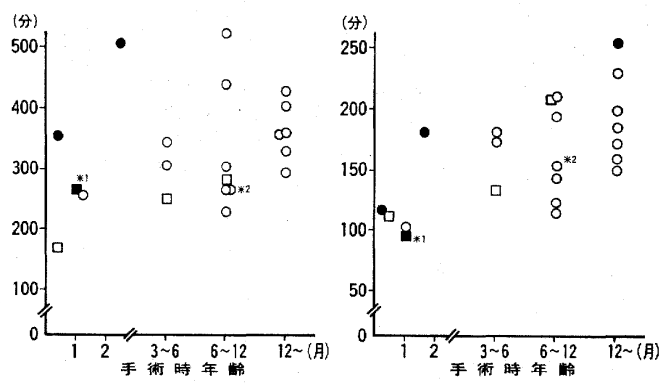

(KAH, June '89)

図 1 開心補助手段（動脈側スイッチ手術 22 例) - : 人工心肺離脱不能, $\bigcirc$ : 低体温体外循環症例, $\square$ : 体外 循環併用超低体温循環遮断症例, ${ }^{* 1}$ : 川島法, ${ }^{* 2}:$ D-K-S

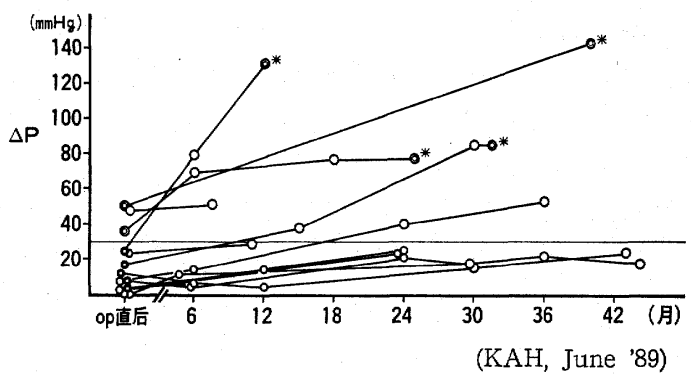

図 2 Jatene 術後の RV-PA 圧較差 $(\Delta P)$ の推移 * : 症例：PS 解除術施行例, (0): 心カテデータ, ○:ドプラエコーデータ

なる傾向を示した.

一方, Jatene 手術後の主要合併症である PS に関し ては，心臓カテーテル検査あるいは心ドプラエコー検査 で右室肺動脈収縮期圧較差 $(\Delta P)$ を経時的に追跡した. 13 例中 6 例に $\Delta P>30 \mathrm{mmHg}$ の有意の PS の発生お よび進行を認めた（図2）．うち4 例に Jatene 手術後 1 年 1 加月～ 3 年 3 加月（平均 2 年 6 加）で再手術を 


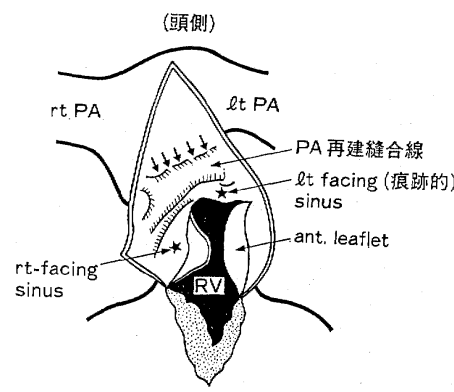

(尾側)

Case \#1

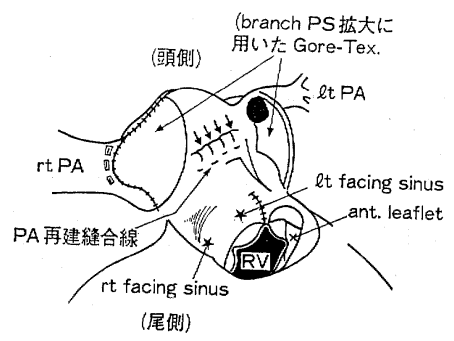

Case $\# 3$

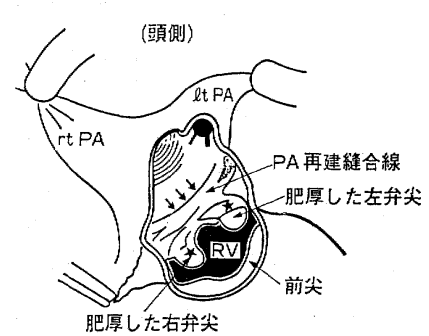

(尾側)

Case $\# 2$

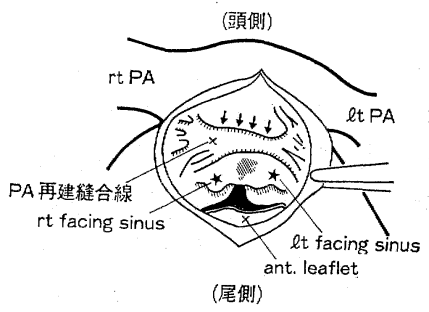

Case \#4

図 3

行った. 再手術前の $\Delta P$ は 63〜 $142 \mathrm{mmHg}$ (平均 103 $\mathrm{mmHg}$ ) であった. 図 3 に一期的に Jatene 手術を行っ た Case \#1, Case\#2 および二期的に Jatene 手術 (PA banding 施行) を行った Case \#3, Case \#4の 再手術時肺動脈所見を示す.

Case \#1：5 加月時 Lecompte 法 Jatene 手術施行， 冠動脈は両側 Panch out で切離し, 自己心膜で補填, 肺動脈再建は後壁は内面より連続縫合を行い, 前面には 数針のU字縫合を置いた. PA 後壁吻合部は, テラス状 (矢印) に内腔に突出し弁上狭窄を呈していた. Right facing sinus cusp は軽度の肥厚のみで可動性は十分保 たれていたが, left facing sinus は Jatene 手術時吻合 部の止血操作によってほとんど消失していた，乙のた め弁輪む狭小化して扣り，右室流出路まで切開を加え MVOP で拡大した.

Case \#2:47日 Lecompte 法 Jatene 手術施行. 冠 動脈は左楔状切離, 右 panch out, 馬心膜で補填, PA 吻合は Case \#1 と同じ. PA 後壁吻合部の内腔突出 (矢印) による弁上狭窄に加えて馬心膜の退縮著明。乙

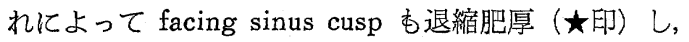
弁性狭窄む呈していた. 自家性一弁付 transannular patch で拡大.

Case \#3: 1 歳 10 か月で Lecompte 法 Jatene 手術
施行. 冠動脈切離法, 補填材料, PA 吻合法は Case \#2 に同じ，吻合部狭窄は認められなかった，Facing sinus は軽度の退縮のみで弁機能は十分に温存され弁性狭窄も なかった. しかし右肺動脈が分岐部で内膜が全周にわた って肥厚し, 左肺動脈は内膜に長軸方向の懗璧が存在し て long narrow channel を形成, 肺動脈分枝狭窄を呈 していた．乙れは大動脈による後方からの王ぱいと，人 工心膜として用いた馬心膜の退縮による constrictive pericarditis に起因すると思われる.

Case \# 4: 1歳 10 か力で Lecompte 法 Jatene 手術 施行. 術式は case \#2, \#3 と同じ. 先に行った PA banding 部組織を十分に切除しなかったため吻合部は 全周にわたって退縮硬化し弁上狭窄が著明であった. Facing sinus の退縮は軽度で弁の形態もよく保たれて おり弁性狭窄は認められなかった.

\section{考察}

TGA に対する動脈側スイッチ手術は成績む安定し, 遠隔予後 ${ }^{5}$ の点からあ第一選択術式としての地位を確立 した.われわれが経験した Senning 手術例にみられる ように術前多血症の進行から肺高血圧，血小板減少をき たす症例に対する動脈側スイッチ手術も血小板大量輸血 療法 $^{6)}$ で十分対処できると考える. 新生児では体外循環 
時間, 大動脈遮断時間の可及的短縮が必要であり, 循環 遮断法はなお有効な手段といえる(図 1 上). また大動 脈遮断中の順行性心筋保護法は大動脈再建までは操作が きわめて繁雑であり，てれに対して逆行性心筋保護法7) あ今後考慮すべき方法である.

Jatene 手術後発生するPS の原因として, 手術年齢, $\mathrm{PA}$ banding ( $\mathrm{PAB}$ ) の有無, 冠動脈切離方法, 補填材 料, PA 吻合法などが考えられる. PAB(一) 群 7 例と $\mathrm{PAB}(+)$ 群 6 例の二群間で Jatene 手術直後之遠隔期 $\triangle P$ の変化を比較した. $\mathrm{PAB}(-)$ 群, 術直後 $25 \pm 18$ $(\mathrm{mmHg})$ 遠隔期 64士50. $\mathrm{PAB}(+)$ 群, 術直後 $18 \pm 13$, 遠隔期 $39 \pm 30$. おのおのの間に統計学的有意差は認めら れなかった. 同様に冠動脈切離方法, 補填材料によって 屯統計学的有意差はなかった. しかし自験例から PS の 主体は吻合部狭窄であり，最近では大血管の再建吻合は 全周結節外反縫合を行っている．補填材料も従来の馬心 膜加自己心膜に変更し比較検討を行っている. Facing siuns の退縮による弁輪狭窄，弁機能不全を予防するた めには補填材料をよく吟味すると同時に facing sinus の 自己組織をできるだけ温存するような切離方法の工夫が 必要と思わ机る。

\section{結語}

1） TGA I，II群および T-B 奇形 97 例に対して心 室, 大血管, 冠動脈の形態により種々の術式を行った. あらゆる type 亿動脈側スイッチ手術の可能性があると 考える.

2）新生児では体外循環時間が手術成績を左右する重 要因子である，循環遮断法は体外循環時間を有意に短縮 し，全身浮腫の軽減に有効であった。

3) Jatene 術後 PS の発生, 進行が $40 \%$ 亿認めら れた. 4 例の手術所見より全例吻合部狭窄が主体であっ た. 現在では大血管の再建は全周結節外反縫合を行って いる. また補填に用いた心膜の退縮による facing sinus の縮小，弁肥厚をきたした症例むあったが，冠動脈の切 離方法, 補填材料との相関は認められなかった.

文 献 1) Damus, P.S.: Ann. Thorac. Surg. 20:724, 1975. 2) Stanse1, H. C., Jr.: Ann. Thorac. Surg. 19: 565, 1975. 3) Kaye, M. P.: Mayo. Clin. Proc. 50: 638, 1975. 4) Lecompte, Y. et al.: J. Thorac. Cardiovasc. Surg. 62 : 629，1981. 5) 岡本文雄ほか：日心外会誌 18：177，1988. 6) 寺井 勝ほ加：日小児会誌 89：2408，1985. 7) 米永國宏 ほ加：日胸外会誌 $37 ： 274,1989$.

\section{S-II-8 完全大血管転位症 I 型に対する新生児乳児期 早期一期的 Jatene 手術}

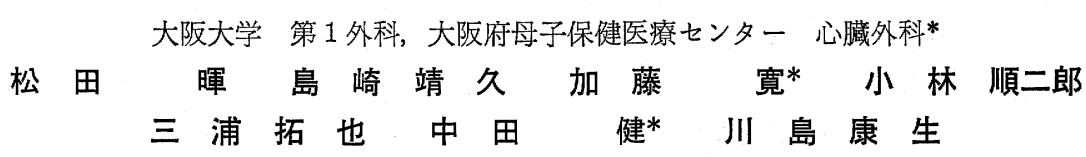

完全大血管転位症に対する Jatene 手術は，心室中隔 欠損を伴わないＩ型に対する第一選択の手術となりつつ ある年 . しかし，乙れを新生児期に一期的に行うか, また一期的手術において術前管理法ならびに手術時期に ついていまだ議論が残されている6).われわれは新生児 期早期に BAS を行い，その後 PGE1を投与した新生 児期後半に手術を行う方針をとってきたのでその成績と 術前後の左室機能を報告する.

\section{対象}

昭和 60 年より 63 年末までに， 2 施設において行った
10 例を対象とした. 1 例を除き，全例生後 7 日以内に 入院し, BAS を施行し, 動脈管開存と左室圧が右室圧 に近いことを確認し PGE 1 の投与を開始した. その後 超音波検查で左室圧の推移を観察しつつ, 生後 11 から 42 日に手術を行った. 新生児期手術は 8 例で生後 27 日 まで, 平均 20 日，その他は 39,42 日であった. 術前 1 例を除き PGE 1 は継続投与した. 手術時左室右室収 縮期圧比 (pLV/RV) は 0.60 から 1.09 で, 全例左室機 能上 Jatene 手術に問題となる機能低下はみられなかっ た. 